\title{
Experimental and Analytical Investigation on the Effect of Heat Treatment Parameters on the Mechanical Properties of an API 5L X65 Steel
}

\author{
Nicki Robbers Darciano Cajueiro de Moraes ${ }^{a}$ (D), Julianna Magalhães Garcia ${ }^{a *}$ (D), \\ Eustáquio de Souza Baêta Júnior ${ }^{(1 D}$, Renato Batista da Cruz ${ }^{a}$ (D), Luiz Paulo Brandao ${ }^{a}$ (D)
}

${ }^{a}$ Instituto Militar de Engenharia (IME), Rio de Janeiro, RJ, Brasil

Received: November 05, 2020; Revised: January 19, 2021; Accepted: January 21, 2021

\begin{abstract}
High Strength Low Alloy steels (HSLA) for oil and gas pipelines should display high mechanical strength, toughness, ductility and weldability. In this work we studied the influence of quenching and tempering temperature on the yield strength, ultimate tensile strength, percent elongation and hardness of API 5L steel pipes in order to optimize heat treatments to be performed after hot induction bending of the material. The thermal cycles involved soaking temperatures of 880,920 and $960{ }^{\circ} \mathrm{C}$, cooling water at 15,23 and $31^{\circ} \mathrm{C}$ and tempering at 530,600 and $670^{\circ} \mathrm{C}$. From this, experimental design techniques were used to reduce the number of experiments. The results from contour maps suggest that soaking temperatures of 910 and $950{ }^{\circ} \mathrm{C}$ and tempering between 540 and $610{ }^{\circ} \mathrm{C}$ were the most suitable for treatment, regarding mechanical strength. The variation of the water temperature was not significant for the assumed cooling conditions. The prediction regression models of the mechanical properties from the variables involved in the heat treatments showed a good fit between the experimental and predicted results, with correlation coefficient between 0.89 and 0.94 .
\end{abstract}

Keywords: API 5L X65, Heat treatment, Hardness, Tensile Test, Statistical Analysis.

\section{Introduction}

The discovery of oil and natural gas in regions subject to severe weather conditions such as the Arctic and the deep sea has resulted in a demand for special steels to be used in pipes $^{1,2}$. These steels must have high strength and toughness, as well as excellent weldability, so extensive research efforts were focused on the development of High Strength Low Alloy Steels (HSLA), today one of the most common steels in this class are known as API 5L $\mathrm{L}^{1-6}$.

In the construction of oil and gas pipelines, it is required that these pipes fit the terrain topography or can be structured in complex networks, bringing out the need to bend some sections for better accommodation ${ }^{7}$. This is usually accomplished using induction bending. Curves with small angles can be fabricated on site by cold bending, but for small radii and large angles, bending is performed by heating a copper coil by electromagnetic induction from a high frequency current ${ }^{7-10}$.

The quality of the final product is determined by the bending angle that can be obtained by the process and the microstructural changes promoted by deformation and/or the thermal cycles imposed during bending. This process involves surface quenching and thermomechanical treatment, since Foucault currents heat the outer layers by the Joule effect and the inner layers are heated by conduction, promoting a gradient heating of the material until austenitization ${ }^{11}$. Plastic deformation is then performed to bend the tube.

This procedure may cause changes in the microstructure and have an adverse effect on the mechanical properties of

*e-mail: julianna@ime.eb.br the steel $^{8}$, that, after bending, may not meet the standards required by API 5L $\mathrm{L}^{12}$. Therefore, it is essential to adjust the heat treatment parameters after bending to recover the desired properties of the steel. However, a laboratorial study of the influence of heat treatment on the mechanical properties of steel requires a large number of experiments, which can make the procedure prohibitively expensive. In this work was used Design of Experiments in order to model an algorithm capable of selecting the best treatment conditions as a way of establishing adequate heat treatment conditions to ensure that the properties of the steel after hot bending meet API 5L Standard ${ }^{12}$.

The thermal cycles considered in this study are designed to obtain the most desirable microstructure and adequate values of tensile strength, yield strength and hardness of API 5L X65 pipe samples. Also, for manufacturing conditions, it is advantageous to have tools for making the prediction of mechanical properties from different heat treatment parameters, permitting operational settings adjustments to achieve the standard requirements. A regression model was developed in this work, from the heat treatment parameters, to predict ultimate tensile strength, yield strength, percent elongation and hardness measurement. The results presented a comparable fit between the experimental and predicted results.

\section{Experimental Procedure}

API 5L PSL 2 seamless pipeline steel, rolled by the Mannesmann process, were used. The tubes employed in this investigation have API 5L X65 certification, an outside 

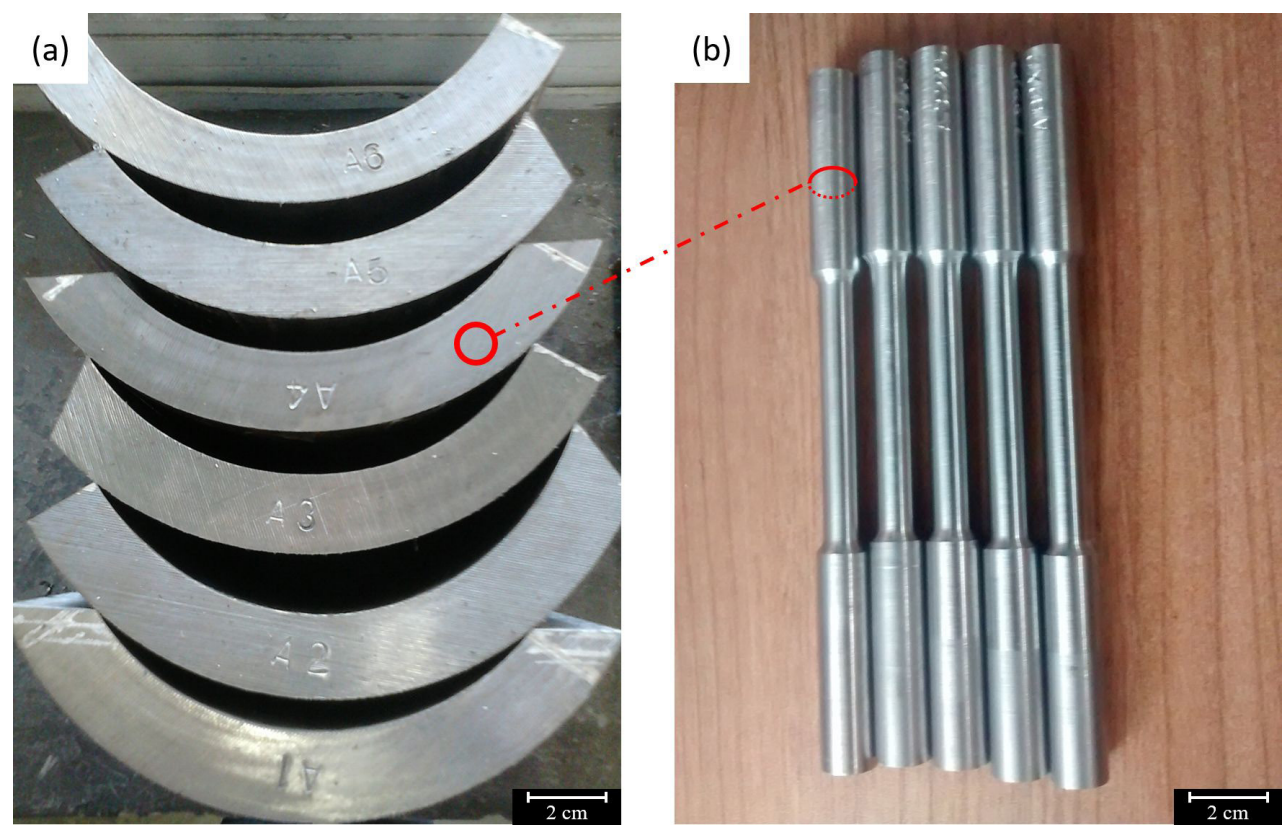

Figure 1. Material API 5L X65 PSL 2 seamless pipeline: a) tube cross-section b) tensile test specimen.

Table 1. Chemical composition of API 5L steel under study.

\begin{tabular}{|c|c|c|c|c|c|c|c|c|c|c|c|c|c|c|c|}
\hline $\mathrm{C}$ & $\mathrm{Mn}$ & $\mathrm{Si}$ & $\mathrm{Ni}$ & $\mathrm{Cr}$ & Mo & $\mathrm{Cu}$ & $\mathrm{P}$ & $\mathrm{S}$ & $\mathrm{Al}$ & $\mathrm{Ti}$ & $\mathrm{Nb}$ & $\mathrm{V}$ & $\mathrm{N}$ & B & $\mathrm{Ca}$ \\
\hline 0.1 & 1.1 & 0.27 & 0.09 & 0.13 & 0.1 & 0.11 & 0.017 & 0.005 & 0.027 & 0.002 & 0.02 & 0.06 & 0.008 & 0.0002 & 0.0014 \\
\hline
\end{tabular}

diameter of $219.1 \mathrm{~mm}$ and a wall thickness of $22.2 \mathrm{~mm}$, Figure 1a. The chemical composition is shown in Table 1. Straight sections of the tubes were extracted along the longitudinal direction in order to manufacture specimens for the tests.

The samples were quenched in cold water, at 15,23 and $31{ }^{\circ} \mathrm{C}$, after complete austenitization at different soaking temperatures of 880,920 and $960{ }^{\circ} \mathrm{C}$, for $60 \mathrm{~min}$. Then they were tempered at 530,600 and $670{ }^{\circ} \mathrm{C}$, for $60 \mathrm{~min}$, and air cooled. Tensile and hardness tests were performed in specimens of each of the above conditions following the ASTM A370 Standard ${ }^{13}$, Figure 1b.

The Design of Experiments (DOE) method was used to determine the relation between factors affecting a parameter and its results, aiming to explore, map and model the response behavior within a range of factors involved. DOE portrays the behavior of a particular process with experimental efficiency and is used to determine the contribution of each factor, model its effect on the response, and resolve factor interactions ${ }^{14-16}$. In this paper, discussions were stated about the effect of soaking, cooling water and tempering temperatures on the steel properties. The chosen temperature variables were settled to oscillate around three levels, i.e. minimum, mean and maximum values, as described in the Table 2. The final analysis of the three levels is performed by Box-Behnken Planning, which allows eliminating extreme experimental conditions and keeps the sets within the mean values. Following the planning, 15 experimental conditions were named and select as shown in Table 3. For each treatment was produced five tensile and five hardness specimens, totalizing 75 specimens respective to its test.
Table 2. Heat treatment variables used for the experimental design.

\begin{tabular}{lccc}
\hline \multicolumn{1}{c}{ Variables } & \multicolumn{3}{c}{ Physical Values } \\
\hline Soaking Temperature $\left({ }^{\circ} \mathrm{C}\right)$ & 880 & 920 & 960 \\
\hline Colling Water Temperature $\left({ }^{\circ} \mathrm{C}\right)$ & 15 & 23 & 31 \\
\hline Tempering Temperature $\left({ }^{\circ} \mathrm{C}\right)$ & 530 & 600 & 670 \\
\hline Levels & - & 0 & + \\
\hline
\end{tabular}

Tensile and hardness tests are performed following the specimens described by standard ASTM A $370^{13}$.

Mathematical equations were generated from experimental data regression using the Statgraphics Centurion XV software to predict mechanical property values from heat treatment variables, i.e., ST (soaking temperature in ${ }^{\circ} \mathrm{C}$ ), CWT (cooling water temperature in ${ }^{\circ} \mathrm{C}$ ) and TT (tempering temperature in ${ }^{\circ} \mathrm{C}$ ).

The proposed regression equations describe the relationship between the heat treatment parameters with its mechanical properties while their determination coefficients $\left(\mathrm{R}^{2}\right)$ express the adjustment quality of the proposed model. From this, the values generated by regression were compared to those obtained experimentally, considering the correspondence values of ultimate tensile strength $\left(R_{m}\right)$, yield strength $\left(\mathrm{R}_{\mathrm{t} 0.5}\right)$, percent elongation $\left(\mathrm{A}_{\mathrm{f}}\right)$, and Hardness Rockwell $\mathrm{B}$ measurement (HRB).

\section{Results and Discussion}

\subsection{Hardness test}

It was statistically verified, using the HRB tests values, that the average hardness was influenced by the heat treatment, 
considering a significance level of 0.05 through t-Student distribution, which enabled a statistically descriptive approach of the data. The experimental results are shown in Table 4. The highest hardness values found are of the experimental conditions A23X and A22Y-M3 (one of the three replicas from A22Y condition - central point of the DOE). High hardness values were also obtained in samples with soaking temperature of $880^{\circ} \mathrm{C}$, cooled in water at $23^{\circ} \mathrm{C}$ and tempered at $530{ }^{\circ} \mathrm{C}(\mathrm{A} 12 \mathrm{X})$ and in samples whose quenching was performed from $960^{\circ} \mathrm{C}$, for all cooling water e tempering temperatures. Test results of samples treated at $920^{\circ} \mathrm{C}$ of soaking, followed by cooling at $31{ }^{\circ} \mathrm{C}$ and tempering at $530{ }^{\circ} \mathrm{C}$ had the lowest hardness value (A23Z).

Discussing the Hardness test results it is important to point out that all samples have not exceeded the maximum hardness value of $25 \mathrm{HRC}$ (102HRB) dictated by the API $5 \mathrm{~L}$ Standard ${ }^{12}$, for offshore services; neither it exceeded 22 HRC (100HRB) expressed by ASME B16.49 Standard ${ }^{17}$. A correlation was observed between hardness and tensile

Table 3. Matrix of experiments outlined by the Box-Behnken method.

\begin{tabular}{cccc}
\hline $\begin{array}{c}\text { Experimental } \\
\text { Condition }\end{array}$ & $\begin{array}{c}\text { Soaking } \\
\text { Temperature } \\
\left({ }^{\circ} \mathrm{C}\right)\end{array}$ & $\begin{array}{c}\text { Colling Water } \\
\text { Temperature } \\
\left({ }^{\circ} \mathrm{C}\right)\end{array}$ & $\begin{array}{c}\text { Tempering } \\
\text { Temperature } \\
\left({ }^{\circ} \mathrm{C}\right)\end{array}$ \\
\hline $\mathrm{A} 11 \mathrm{Y}$ & - & - & 0 \\
\hline $\mathrm{A} 31 \mathrm{Y}$ & + & - & 0 \\
\hline $\mathrm{A} 13 \mathrm{Y}$ & - & + & 0 \\
\hline $\mathrm{A} 33 \mathrm{Y}$ & + & + & 0 \\
\hline $\mathrm{A} 12 \mathrm{X}$ & - & 0 & - \\
\hline $\mathrm{A} 32 \mathrm{X}$ & + & 0 & - \\
\hline $\mathrm{A} 12 \mathrm{Z}$ & - & 0 & + \\
\hline $\mathrm{A} 32 \mathrm{Z}$ & + & 0 & + \\
\hline $\mathrm{A} 21 \mathrm{X}$ & 0 & - & - \\
\hline $\mathrm{A} 23 \mathrm{X}$ & 0 & + & - \\
\hline $\mathrm{A} 21 \mathrm{C}$ & 0 & - & + \\
\hline $\mathrm{A} 23 \mathrm{C}$ & 0 & + & + \\
\hline $\mathrm{A} 22 \mathrm{Y}-\mathrm{M} 1$ & 0 & 0 & 0 \\
\hline $\mathrm{A} 22 \mathrm{Y}-\mathrm{M} 2$ & 0 & 0 & 0 \\
\hline $\mathrm{A} 22 \mathrm{Y}-\mathrm{M} 3$ & 0 & 0 & 0 \\
\hline
\end{tabular}

results, that is, high hardness was associated with high strength. Considering the as-received sample, which presented 20.4 HRC (97 HRB), only A22Y-M3 and A23X conditions exhibited higher HRB, and correspondingly, also presented the highest results of Yield Strength $\left(\mathrm{R}_{\mathrm{t} 0.5}\right)$ and Ultimate Tensile Strength $\left(\mathrm{R}_{\mathrm{m}}\right)$, showing the conformity of the traditional direct relationship between tensile mechanical strength and hardness for the steels.

Chung et al. ${ }^{18}$ also worked with API 5L X65 steel and investigated different heat treatments conditions regarding the microstructural evolution, Vickers hardness (HV) and Charpy V-notch impact toughness tests. The authors observed that after quenching at $950{ }^{\circ} \mathrm{C}$ and tempering from the range of 500 to $600{ }^{\circ} \mathrm{C}$ they obtained average $250 \mathrm{HV}$ (99 HRB), which is comparable with the results obtained in this investigation.

\subsection{Tensile test}

Table 5 introduces the tensile properties obtained for all analyses. In this table, the values specified by the API $5 \mathrm{~L}$ Standard $^{12}$ for the X65 grade steel considered in this investigation and as-received properties are presented. The first important conclusion of the Table 5 analysis is that the treatments greatly influenced the mechanical properties assessed on tensile test. Besides that, the samples have also met most of the standard requirements after the heat treatment, indicating the adhesion of these treatments as one way to recover the original API 5L X65 properties. The minimum expected elongation for the used specimens, in API 5L Standard ${ }^{12}$, is $15.4 \%$, using equation $\mathrm{Af}=\mathrm{C}\left(\mathrm{Axc}^{\wedge} 0.2\right) /\left(\mathrm{U}^{\wedge} 0.9\right)^{12}$, where $\mathrm{C}=1940, A_{x c}=$ cross-section with $8.75 \mathrm{~mm}$ diameter and $\mathrm{U}=$ specified minimum tensile strength. However, following ASME B16.49 Standard $^{17}$, 18\% minimum elongation is required for X65 pipes. Considerering the most demanding condition, it was used $18 \%$ for the evaluation.

The sample A23Z is the only one that did not meet API 5L Standard ${ }^{12}$ in its Yield Strength $\left(\mathrm{R}_{\mathrm{t} 0.5}\right)$ and Ultimate Tensile Strength $\left(\mathrm{R}_{\mathrm{m}}\right)$, while A23X achieved the highest $\mathrm{R}_{\mathrm{t} 0.5}$ and $\mathrm{R}_{\mathrm{m}}$. The only difference between them is the tempering temperature, thus showing its high influence on the mechanical

Table 4. Sample hardness test results.

\begin{tabular}{ccccccc}
\hline $\begin{array}{c}\text { Experimental } \\
\text { Conditions }\end{array}$ & I & II & III & IV & V & HRB \\
\hline A11Y & 91 & 88 & 87 & 88 & 92 & $89.20 \pm 2.69$ \\
\hline A12X & 98 & 91 & 89 & 88 & 90 & $91.20 \pm 4.92$ \\
\hline A12Z & 86 & 85 & 84 & 84 & 83 & $84.40 \pm 1.42$ \\
\hline A13Y & 89 & 88 & 87 & 87 & 90 & $88.20 \pm 1.62$ \\
\hline A21X & 90 & 90 & 90 & 93 & 93 & $91.20 \pm 2.04$ \\
\hline A21Z & 89 & 90 & 90 & 90 & 88 & $89.40 \pm 1.11$ \\
\hline A22Y-M1 & 95 & 95 & 95 & 96 & 96 & $95.40 \pm 0.68$ \\
\hline A22Y-M2 & 91 & 93 & 94 & 96 & 96 & $94.00 \pm 2.63$ \\
\hline A22Y-M3 & 99 & 97 & 96 & 97 & 98 & $97.40 \pm 1.42$ \\
\hline A23X & 100 & 99 & 98 & 96 & 97 & $98.00 \pm 1.96$ \\
\hline A23Z & 77 & 78 & 85 & 83 & 82 & $81.00 \pm 4.21$ \\
\hline A31Y & 93 & 94 & 94 & 94 & 92 & $93.40 \pm 1.11$ \\
\hline A32X & 93 & 93 & 93 & 93 & 93 & 93.00 \\
\hline A32Z & 81 & 89 & 92 & 92 & 92 & $89.2 \pm 5.91$ \\
\hline A33Y & 92 & 93 & 95 & 96 & 96 & $94.40 \pm 2.26$ \\
\hline
\end{tabular}


Table 5. Sample tensile test results.

\begin{tabular}{|c|c|c|c|c|c|c|c|c|}
\hline $\begin{array}{c}\text { Experimental } \\
\text { Conditions }\end{array}$ & $\mathrm{R}_{\mathrm{t} 0.5}(\mathrm{MPa})$ & API X65 & $\mathrm{R}_{\mathrm{m}}(\mathrm{MPa})$ & API X65 $65^{12}$ & $\mathrm{~A}_{\mathrm{f}}(\%)$ & API X $65^{17}$ & Ratio & API X $65^{1:}$ \\
\hline$A 11 Y$ & 509.32 & \multirow{16}{*}{$450<\mathrm{R}_{\mathrm{t} 0.5}<600$} & 587.03 & \multirow{16}{*}{$535<\mathrm{R}_{\mathrm{m}}<760$} & 22.70 & \multirow{16}{*}{$18<\mathrm{A}_{\mathrm{f}}$} & 0.87 & \multirow{16}{*}{$\mathrm{R}<0.93$} \\
\hline$A 12 X$ & 516.20 & & 605.89 & & 21.19 & & 0.85 & \\
\hline$A 12 Z$ & 452.62 & & 527.58 & & 24.64 & & 0.86 & \\
\hline$A 13 Y$ & 512.82 & & 590.81 & & 22.35 & & 0.87 & \\
\hline$A 21 X$ & 578.81 & & 667.06 & & 16.39 & & 0.87 & \\
\hline$A 21 Z$ & 483.60 & & 564.53 & & 21.39 & & 0.86 & \\
\hline$A 22 Y-M 1$ & 598.93 & & 680.33 & & 18.29 & & 0.88 & \\
\hline$A 22 Y-M 2$ & 597.73 & & 672.94 & & 18.65 & & 0.89 & \\
\hline$A 22 Y-M 3$ & 598.88 & & 675.54 & & 17.70 & & 0.89 & \\
\hline$A 23 X$ & 625.19 & & 697.05 & & 17.02 & & 0.90 & \\
\hline$A 23 Z$ & 407.11 & & 505.53 & & 23.89 & & 0.81 & \\
\hline$A 31 Y$ & 551.68 & & 638.38 & & 17.69 & & 0.86 & \\
\hline$A 32 X$ & 531.02 & & 632.59 & & 16.72 & & 0.84 & \\
\hline$A 32 Z$ & 463.74 & & 569.56 & & 21.92 & & 0.81 & \\
\hline$A 33 Y$ & 597.48 & & 677.86 & & 16.78 & & 0.88 & \\
\hline As-received & 467.63 & & 556.75 & & 22.32 & & 0.84 & \\
\hline
\end{tabular}

properties, which is further discussed in the following section of discussions on the Average Effect Analysis and ANOVA. One can also observe that $\mathrm{A} 12 \mathrm{Z}$ did not meet the $\mathrm{R}_{\mathrm{m}}$ standard requirement. Once again, the highest tempering condition resulted in a low tensile strength.

As for the tensile properties, the quenching and tempering heat treatment promoted a significant increase in the $\mathrm{R}_{\mathrm{t} 0.5}$ and $\mathrm{R}_{\mathrm{m}}$ in most of the samples. Only the specimens tempered at $670{ }^{\circ} \mathrm{C}$ presented stress properties worse than those of the as-received material results. Comparing the average condition (A22Y), defined by the Box-Behnken Planning, with the as-received material, one can observe an increase of $28 \%$ and $21 \%$ in the $\mathrm{R}_{\mathrm{t} 0.5}$ and $\mathrm{R}_{\mathrm{m}}$, respectively, accompanied by a small ductility loss of $18 \%$. A23Z, which was tempered at $670{ }^{\circ} \mathrm{C}$, did not achieve the strength requirements by the Standard ${ }^{12}$, having a reduction of $13 \%$ and $9 \%$ in the $\mathrm{R}_{\mathrm{t} 0.5}$ and $\mathrm{R}_{\mathrm{m}}$, respectively, and an increase of $7 \%$ on the ductility, in comparison to the as-received material. As expected, high $\mathrm{R}_{\mathrm{t} 0.5}$ and $\mathrm{R}_{\mathrm{m}}$ results in low percent elongation and vice-versa, showing the need to examine in detail the relation between the heat treatment temperature and the resulting properties in order to optimize the process.

For the sake of studying the influence of each treatment condition, an analysis of the Average Effect of the Variables was performed. For this, soaking temperature was named as ST, cooling water temperature as CWT and tempering temperature as TT, and they were considered as factors that modify $\mathrm{R}_{\mathrm{t} 0.5}, \mathrm{R}_{\mathrm{m}}$ and percent elongation $\left(\mathrm{A}_{\mathrm{f}}\right)$. The graphical visualization of the influence of those variables on the tensile properties are shown in Figure 2.

The highest $\mathrm{R}_{\mathrm{t} 0.5}$ values were observed for a soaking and tempering temperature around $930{ }^{\circ} \mathrm{C}$ and $570{ }^{\circ} \mathrm{C}$, respectively. A similar behavior was observed for the $R_{m}$. Regarding the elongation, the opposite effect was detected; as the temperature increases, the elongation decreases in almost the entire soaking curve. The highest elongation was found at the lowest temperature, $880{ }^{\circ} \mathrm{C}$.

The temperatures employed in the quenching and tempering heat treatments have a strong influence on the (a)

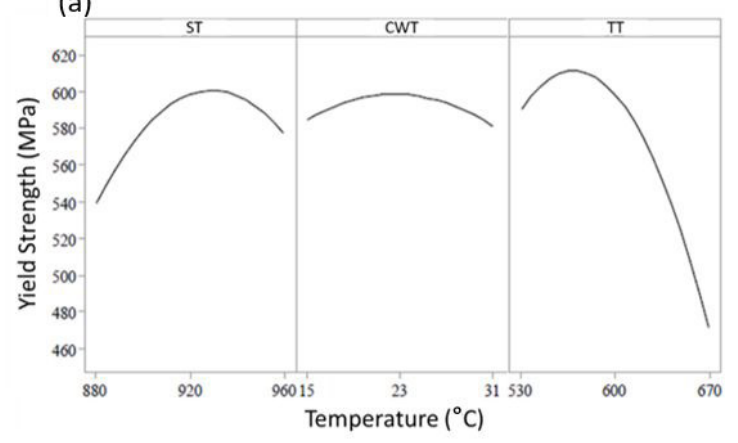

(b)

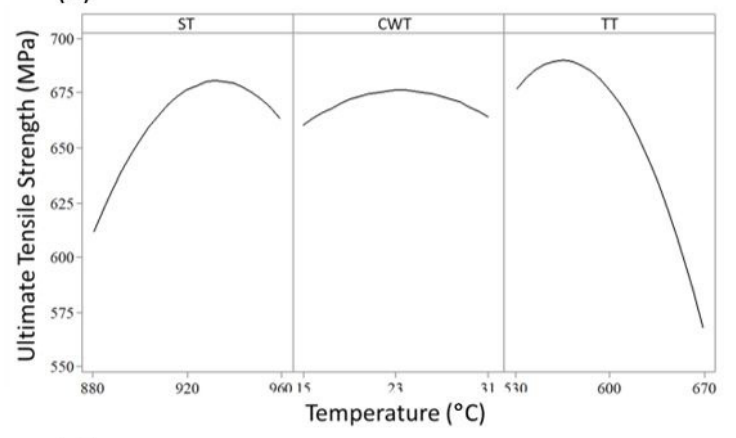

(c)

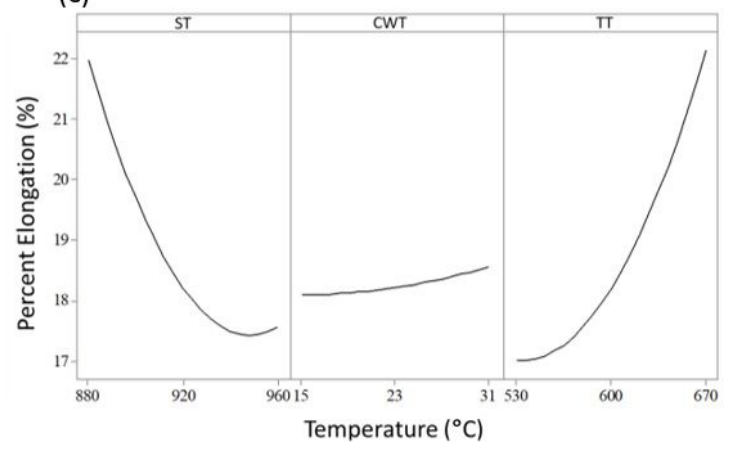

Figure 2. Average Effect of the heat treatment variables on a) $\mathrm{R}_{\mathrm{t} 0.5}$, b) $R_{m}$ and c) $A_{f}$. 
$\mathrm{R}_{\mathrm{t} 0.5}, \mathrm{R}_{\mathrm{m}}$ and $\mathrm{A}_{\mathrm{f}}$ limits. The variation of the cooling water temperature tested in this program did not show a significant influence on the mechanical properties, resulting in very similar values. This casts doubt on the need of controlling the water temperature. It connotes that water cooling would require a high energy consumption without significant improving the steel properties.

As can be further discussed by the Analysis of Variance, Table 6, cooling water temperature group has calculated $\mathrm{F}$ smaller than the critical F (3.885), for yield and ultimate strength. Specially, if we analyze the cooling water interaction with soaking water, has the lowest significance for the results of $\mathrm{R}_{\mathrm{t} 0.5}$ and $\mathrm{R}_{\mathrm{m}}$. As for the elongation, all parameters showed enough significance to be considered during calculations. On the other hand, soaking and tempering temperatures have a calculated $\mathrm{F}$ greater than the critical. In particular TT, showed the biggest influence in the results of all parameters $\left(\mathrm{R}_{\mathrm{t} 0.5}, \mathrm{R}_{\mathrm{m}}\right.$ and $\left.\mathrm{A}_{\mathrm{f}}\right)$, its interaction with the others temperatures, was all significant. Therefore, the ANOVA reasserts the experimentally observed low influence of the cooling water temperature to the tensile properties of the material after the heat treatment.

The Average Effects of the Variables graphs, as previously shown in Figure 2, summarize the isolated effects of heat treatment variables on the evaluated mechanical properties, not necessarily demonstrating the synergistic effects between the variables, i.e., they do not provide information on the interaction between the heat treatments.

In order to study simultaneously the influence of quenching and tempering on the mechanical properties, contour plots were generated keeping the cooling water temperature at $23{ }^{\circ} \mathrm{C}$ and varying the soaking and tempering temperatures. The contour plots for $\mathrm{R}_{\mathrm{t} 0.5}, \mathrm{R}_{\mathrm{m}}$ and $\mathrm{A}_{\mathrm{f}}$ are shown in Figure 3 .

The plots indicate that the soaking temperatures of 910 and $950{ }^{\circ} \mathrm{C}$ were the most suitable for quenching. It is also observed that tempering temperatures between 540 and $610^{\circ} \mathrm{C}$ have a positive effect on the tensile properties, if associated with an adequate quenching temperature. These combinations resulted in the highest $\mathrm{R}_{\mathrm{t} 0.5}$ and $\mathrm{R}_{\mathrm{m}}$ for these temperatures intervals while, as expected, they were detrimental for the elongation. As reported by Oliveira ${ }^{19}$ for a similar steel, regarding the mechanical properties, the thermal cycle routes that optimized the mechanical properties were soaking at 920 and $960{ }^{\circ} \mathrm{C}$ and tempering at $600{ }^{\circ} \mathrm{C}$, corroborating the results obtained in this investigation. Chung et. al. ${ }^{18}$, who worked in these temperature ranges for other X65 steel, observed that after quenching at $950{ }^{\circ} \mathrm{C}$ and tempering at $600{ }^{\circ} \mathrm{C}$ the steel met the required absorbed energy when tested at $-20{ }^{\circ} \mathrm{C}$. Therefore, this temperature range is in accordance with the results obtained in the present research.
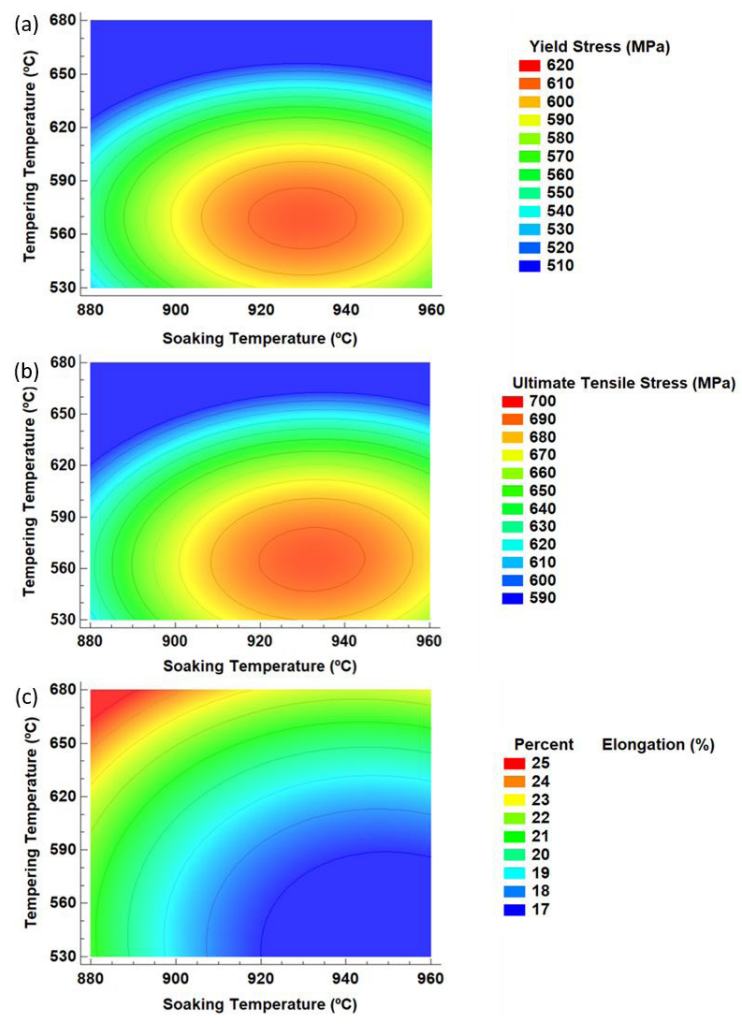

Figure 3. Contour plot for a) $R_{t 0.5}$, b) $R_{m}$ and c) $A_{f^{\prime}}$

\subsection{Regression models}

Regression equations have been developed to describe the relationship between the heat treatment parameters with its mechanical properties. These relations are shown as followed:

$$
\begin{aligned}
& R_{t 0.5}=-26108.3+46.1373 \cdot S T+22.0963 \cdot C W T+ \\
& 17.5577 \cdot T T-0.0251205 \cdot S T^{2}-0.242099 \cdot C W T^{2}- \\
& 0.0137599 \cdot T T^{2}+0.0330516(\cdot 1 S T \cdot C W T- \\
& 0.000329464 \cdot S T \cdot T T-0.0692875 \cdot C W T \cdot T T
\end{aligned}
$$

\begin{tabular}{|c|c|c|c|c|c|c|c|c|}
\hline \multicolumn{9}{|c|}{ Soaking Temperature (ST) } \\
\hline \multicolumn{3}{|c|}{ Yield Strength } & \multicolumn{3}{|c|}{ Ultimate Tensile Strength } & \multicolumn{3}{|c|}{ Percent Elongation } \\
\hline$F$ & Int. $C W T$ & Int. TT & $F$ & Int. $C W T$ & Int. $T T$ & $F$ & Int. $C W T$ & Int. TT \\
\hline 288.97 & 1.1681 & 399.92 & 353.62 & 1.6134 & 444.83 & 22.14 & 84.735 & 50.595 \\
\hline \multicolumn{9}{|c|}{ Cooling Water Temperature (CWT) } \\
\hline \multicolumn{3}{|c|}{ Yield Strength } & \multicolumn{3}{|c|}{ Ultimate Tensile Strength } & \multicolumn{3}{|c|}{ Percent Elongation } \\
\hline$F$ & Int. ST & Int. TT & $F$ & Int. ST & Int. $T T$ & $F$ & Int. ST & Int. TT \\
\hline 0.6444 & 1.1681 & 123.64 & 0.8369 & 1.6134 & 141.97 & 38.66 & 84.735 & 91.642 \\
\hline \multicolumn{9}{|c|}{ Tempering Temperature (TT) } \\
\hline \multicolumn{3}{|c|}{ Yield Strength } & \multicolumn{3}{|c|}{ Ultimate Tensile Strength } & \multicolumn{3}{|c|}{ Percent Elongation } \\
\hline$F$ & Int. $S T$ & Int. $C W T$ & $F$ & Int. ST & Int. $C W T$ & $F$ & Int. ST & Int. $C W T$ \\
\hline 657.90 & 399.92 & 123.64 & 750.01 & 444.83 & 141.97 & 40.39 & 50.595 & 91.642 \\
\hline
\end{tabular}

Table 6. Variance analysis of the studied variables. 
Table 7. Measured and predicted results of mechanical properties.

\begin{tabular}{ccccccccc}
\hline $\begin{array}{c}\text { Exp. } \\
\text { Conditions }\end{array}$ & $\begin{array}{c}\text { Measured } \\
\mathrm{R}_{\mathrm{t} 0.5}(\mathrm{MPa})\end{array}$ & $\begin{array}{c}\text { Predicted } \\
\mathrm{R}_{\mathrm{t} 0.5}(\mathrm{MPa})\end{array}$ & $\begin{array}{c}\text { Measured } \mathrm{R}_{\mathrm{m}} \\
(\mathrm{MPa})\end{array}$ & $\begin{array}{c}\text { Predicted } \mathrm{R}_{\mathrm{m}} \\
(\mathrm{MPa})\end{array}$ & $\begin{array}{c}\text { Measured } \mathrm{A}_{\mathrm{f}} \\
(\%)\end{array}$ & $\begin{array}{c}\text { Predicted } \mathrm{A}_{\mathrm{f}} \\
(\%)\end{array}$ & $\begin{array}{c}\text { Measured } \\
\mathrm{HRB}\end{array}$ & $\begin{array}{c}\text { Predicted } \\
\mathrm{HRB}\end{array}$ \\
\hline$A 11 Y$ & 509.32 & 535.55 & 587.03 & 613.09 & 22.70 & 21.14 & 89.20 & 89.86 \\
\hline$A 12 X$ & 516.20 & 530.10 & 605.89 & 624.28 & 21.19 & 20.69 & 91.20 & 91.74 \\
\hline$A 12 Z$ & 452.62 & 412.72 & 527.58 & 508.50 & 24.64 & 24.82 & 84.40 & 82.89 \\
\hline$A 13 Y$ & 512.82 & 511.12 & 590.81 & 598.89 & 22.35 & 21.89 & 88.20 & 88.47 \\
\hline$A 21 X$ & 578.81 & 537.68 & 667.06 & 647.29 & 16.39 & 16.80 & 91.20 & 89.96 \\
\hline$A 21 Z$ & 483.60 & 496.06 & 564.53 & 583.62 & 21.39 & 20.86 & 89.40 & 90.21 \\
\hline$A 22 Y-M 1$ & 598.93 & 598.15 & 680.33 & 684.99 & 18.29 & 17.60 & 95.40 & 95.59 \\
\hline$A 22 Y-M 2$ & 597.73 & 598.15 & 672.94 & 684.99 & 18.65 & 17.60 & 94.00 & 95.59 \\
\hline$A 22 Y-M 3$ & 598.88 & 598.15 & 675.54 & 684.99 & 17.70 & 17.60 & 97.40 & 95.59 \\
\hline$A 23 X$ & 625.19 & 612.00 & 697.05 & 695.44 & 17.02 & 16.32 & 98.00 & 97.16 \\
\hline$A 23 Z$ & 407.11 & 415.17 & 505.53 & 542.78 & 23.89 & 22.26 & 81.00 & 82.21 \\
\hline$A 31 Y$ & 551.68 & 552.65 & 638.38 & 647.75 & 17.69 & 16.94 & 93.40 & 93.11 \\
\hline$A 32 X$ & 531.02 & 570.19 & 632.59 & 669.18 & 16.72 & 15.32 & 93.00 & 94.49 \\
\hline$A 32 Z$ & 463.74 & 449.12 & 569.56 & 568.63 & 21.92 & 21.20 & 89.2 & 88.64 \\
\hline$A 33 Y$ & 597.48 & 570.52 & 677.86 & 669.26 & 16.78 & 17.11 & 94.40 & 93.71 \\
\hline
\end{tabular}

Table 8. Determination $\left(\mathrm{R}^{2}\right)$ and correlation ( $\mathrm{r}$ ) coefficients of the developed mathematical models.

\begin{tabular}{lccc}
\hline \multicolumn{1}{c}{ Mechanical Property } & Equation & $\mathrm{R}^{2}(\%)$ & $\mathrm{r}$ \\
\hline Yield Strength & $(1)$ & 83.7 & 0.91 \\
\hline Ultimate Tensile Strength & $(2)$ & 88.1 & 0.94 \\
\hline Percent Elongation & $(3)$ & 81.3 & 0.90 \\
\hline Hardness Rockwell B & $(4)$ & 78.9 & 0.89 \\
\hline
\end{tabular}

$R_{m}=-23192+43,69 \cdot S T+8.5 \cdot C W T+12.03 \cdot T T-0.02418 \cdot S T^{2}$

$-0.2196 \cdot C W T^{2}-0.01095 \cdot T T^{2}+0.0279 \cdot S T \cdot C W T$

$+0.00136 \cdot S T \cdot T T-0.03973 \cdot C W T \cdot S T$

$A_{f}=1058-1.928 \cdot S T-0.142 \cdot C W T-0.457 \cdot T T+0.000972 \cdot S T^{2}$

$+0.00172 \cdot C W T^{2}+0.000275 \cdot T T^{2}-0.000445 \cdot S T \cdot C W T$

$+0.000156 \cdot S T \cdot T T+0.000835 \cdot C W T \cdot T T$

$H R B=-1383.56+2.58772 \cdot S T+3.99252 \cdot C W T+$

$0.781633 \cdot T T-0.00148438 \cdot S T^{2}-0.0300781 \cdot C W T^{2}-$

$0.0007770408 \cdot T T^{2}+0.0015625 \cdot S T \cdot C W T+$

$0.000267857 \cdot S T \cdot T T-0.00678571 \cdot C W T \cdot T T$

The adequacy of the developed mechanical property models is shown in Table 7, where one can observe the correlation among the measured and the predicted (calculated) properties of the API 5L steel studied. The largest individual error and highest percentual variation in comparison to the experimental data for $\mathrm{R}_{\mathrm{t} 0.5}$ and $\mathrm{R}_{\mathrm{m}}$ were $41.1 \mathrm{MPa}, 9 \%$ and $37.2 \mathrm{MPa}, 7 \%$ and for $\mathrm{A}_{\mathrm{f}}$ and $\mathrm{HRB}$ were $1.6 \%, 8 \%$ and 1.6 , $2 \%$, respectively.

The proposed mathematical modeling quality can be analyzed from the coefficient $r$, obtained by correlation between the calculated data and respective experimental values obtained from mechanical tests. The correlation coefficients drew out from the respective mathematical modeling are summarized in the Table 8 .

It was found that the measured and predicted values presented a comparable fit, with their correlation coefficients between 0.89 and 0.94 and percentual variations that oscillate from $-9 \%$ to $7 \%$. It can be stated that the equations demonstrated effectiveness in predicting the mechanical properties as yield strength, ultimate tensile strength, percent elongation, and hardness Rockwell $\mathrm{B}$, because of the strong correlation between the regression models and experimental results.

The predictive model obtained is expected to help in choosing the heat treatment parameters in order to optimize the operational decision-making processes. Therefore, promoting that certain component achieves the mechanical properties established in the standard requirements.

\section{Conclusion}

According to the results and discussions of this research, some conclusions can be high- lighted:

- $\quad$ Samples quenched at $880{ }^{\circ} \mathrm{C}$ and tempered at 530 and $600{ }^{\circ} \mathrm{C}$ as well as samples with a soaking temperature of $920{ }^{\circ} \mathrm{C}$ and tempered at $670{ }^{\circ} \mathrm{C}$ achieved mechanical properties that meet the requirements of API 5L standard for a X65 steel;

- Under laboratorial scale conditions, a cooling water temperature interval from 15 to $31{ }^{\circ} \mathrm{C}$ for the quenching treatment had no significant effect on the mechanical properties. In fact, all properties investigated did not exhibit significant dependence on the water temperature, as confirmed by the ANOVA;

- The experimental planning methodology, using Design of Experiments, allowed a reduction of the number of tests without compromising the evaluations and helped to optimize the parameters for the heat treatment, showing that the experimental design is effective and can be used in thermomechanical analysis of different materials; 
- The model developed in this investigation suggest that the heat treatment parameters that optimize the mechanical strengths of the HSLA steel used are localized in the red region of the contour plots, i.e., soaking temperatures between 910 and $950{ }^{\circ} \mathrm{C}$ and tempering from 540 to $610^{\circ} \mathrm{C}$;

- A predictive model using regression analysis of experimental data using the Statgraphics Centurion $\mathrm{XV}$ software was thoroughly developed. The model has proved to be very efficacious and beneficial. It can be used to design heat treatment parameters and predict the outcomings mechanical properties of the API 5L x65 steel studied, with a focus on its $\mathrm{R}_{\mathrm{m}}, \mathrm{R}_{\mathrm{t} 0.5}, \mathrm{~A}_{\mathrm{f}}$ and HRB. The proposed predictive models for determining these properties are expected to ensure that engineers are equipped with reliable tools to pre-determining the material properties and ensure that heat treatments are properly planned and effective.

\section{Acknowledgments}

The authors thank the support to this investigation by the Brazilian agencies: CNPq, CAPES and FAPERJ.

\section{References}

1. Masoumi M, Herculano LFG, Abreu HFGD. Study of texture and microstructure evaluation of steel API 5L X70 under various thermomechanical cycles. Mater Sci Eng A. 2015;639:550-8.

2. El-Danaf E, Baig M, Almajid A, Alshalfan W, Al-Mojil M, Al-Shahrani S. Mechanical, microstructure and texture characterization of API X65 steel. Mater Des. 2013;47:529-38.

3. Nafisi S, Arafin MA, Collins L, Szpunar J. Texture and mechanical properties of API X100 steel manufactured under various thermomechanical cycles. Mater Sci Eng A. 2012;531:2-11.

4. Sami Z, Tahar S, Mohamed H. Microstructure and Charpy impact properties of ferrite-martensite dual phase API X70 line pipe steel. Mater Sci Eng A. 2014;598:338-42.

5. Hashemi SH. Strength-hardness statistical correlation in API X65 steel. Mater Sci Eng A. 2011;528(3):1648-55.

6. Kim DW, Kim WK, Bae JH, Choi WD, Sohn SS, Lee S. Effects of finish rolling temperature and yield ratio on variations in yield strength after pipe-forming of API-X65 line-pipe steels. Sci Rep. 2020;10(1):1-2.

7. Hashimoto T, Komizo Y, Sawamura T, Nakade H, Nakatsuka Y. High strength hot-bent pipe for arctic use. T Iron Steel I Jpn. 1986;26(5):418-24

8. Jankejech P, Fabian P, Broncek J, Shalapko Y. Influence of tempering on mechanical properties of induction bents below $540^{\circ} \mathrm{C}$. Acta Mech Autom. 2016;10(2):81-6.

9. Silva R, Pinto A, Kuznetsov A, Bott I. Precipitation and grain size effects on the tensile strain- hardening exponents of an API X80 steel pipe after high-frequency hot-induction bending. Metals. 2018;8(3):168.

10. Arakawa T, Nishimura K, Yano K, Suzuki N. Development of high performance UOE pipe for linepipe. JFE TR. 2013;(18):2335 .

11. Silva RA, Batista GZ, Souza LFGD, Bott IS. Effect of varying high frequency induction bending on the longitudinal SAW weld of API X80 steel pipe. Mater Sci Forum. 2012;706-709:205965.

12. American Petroleum Institute-API. API SPEC 5L: specification for line pipe. 46th ed. New York: API; 2018.

13. American Society for Testing and Materials - ASTM. ASTM A370: standard test methods and definitions for mechanical testing of steel products. Philadelphia: ASTM; 2020.

14. Gonzalez-Pociño A, Alvarez-Antolin F, Asensio-Lozano J. Optimization of quenching and tempering parameters for the precipitation of $\mathrm{M} 7 \mathrm{C} 3$ and $\mathrm{MC}$ secondary carbides and the removal of the austenite retained in vanadis 10 tool steel. Metals. 2019;9(6):627.

15. Bowden GD, Pichler BJ, Maurer A. A Design of Experiments (DoE) approach accelerates the optimization of coppermediated 18F-fluorination reactions of arylstannanes. Sci Rep. 2019;9(1):11370.

16. Campanelli SL, Contuzzi N, Posa P, Angelastro A. Study of the aging treatment on selective laser melted maraging 300 steel. Mater Res Express. 2019;6(6):066580.

17. American Society of Mechanical Engineers - ASME. ASME B16.49: factory-made, wrought steel, buttwelding induction bends for transportation and distribution systems. New York: ASME; 2017.

18. Chung PC, Ham Y, Kim S, Lim J, Lee C. Effects of postweld heat treatment cycles on microstructure and mechanical properties of electric resistance welded pipe welds. Mater Des. 2012;34:685-90.

19. Oliveira RV. Tratamento térmico de um tubo de aço API $5 \mathrm{~L}$ X65 utilizado em curvamento por indução [dissertation]. Rio de Janeiro: Instituto Militar de Engenharia; 2014. 